\title{
ADAPTING URBAN HEAT ISLAND MITIGATION STRATEGY ON BANDUNG DOWNTOWN AREA
}

\author{
Petrus N. Indradjati ${ }^{*}{ }^{*}$, Iztirani Nur Aisha ${ }^{1}$ \\ ${ }^{1}$ School of Architecture, Planning and Policy Development. Institut Teknologi Bandung (ITB). \\ Jl. Ganesha No. 10, Bandung 40132, Indonesia. \\ *Corresponding author; Email: natalivan@sappk.itb.ac.id
}

\begin{abstract}
Urban Heat Island (UHI) mitigation research has been carried out for a long time but it requires to be sharpened to enrich mitigation strategies. In Bandung, maximum temperature has been increasing from $33^{\circ} \mathrm{C}$ to $35^{\circ} \mathrm{C}$ in 30 years. Bandung is getting hotter which can exaggerate the negative impact of UHI mainly in the downtown area. Suitable UHI mitigation strategies are needed to lower urban temperature. UHI mitigation has involved the use of heat-absorbing and covering man-made materials with vegetation such as green wall and roof system. Content analysis of UHI precedents and some preliminary studies are applied to assess prerequisites of UHI mitigation. The analysis showed adaptation opportunities of UHI mitigation strategy on buildings and environmental physical components. The mitigation strategies may vary depending on the typology of buildings (roof and wall) by using reflective materials, while outside the building by increasing vegetation to maximize evaporation to lower the temperature.
\end{abstract}

Keywords: Urban heat island; mitigation; Bandung.

\section{INTRODUCTION}

The increased in human activity as well as rapid development of built area causing the increasing temperature in urban area called urban heat island (UHI). UHI characterized as 'island' of hot air centered in urban areas, especially in the downtown area. UHI occurs because there is a dominance of artificial material that holds heat (heat storage) in urban areas which cause the increase of temperature. Hot temperatures in urban area are also triggered by the release of heat from anthropogenic activities such as industrial activities and urban transport. Akbari and Kolokotsa (2016) suggested that horizontal surfaces in urban areas (such as roofs and pavement) absorbed significantly solar radiation nearly $50 \%$ of this absorbed energy is convected to the air, leading to higher ambient air temperatures. There are two mitigation technologies to reduce the impact of urban warming, first by increasing solar reflectance and secondly by increasing evapotranspiration (Santamouris, 2014).

The main focus of UHI mitigation is to modify the surface of the city with a high heat absorption characteristics. UHI mitigation strategy must suitable with urban design elements especially mass and building form; green space; preservation area, and pedestrian walk. The application of UHI mitigation strategy will vary between cities according to the physical characteristics and the structure of the existing space in the city.
Although over the past three decades the mitigation research focus has been on developing materials, methods and policies to change the landscape and structure of urban buildings, research is still needed to sharpen studies in this field (Akbari and Kolokotsa, 2016). In Indonesia, research conducted generally looks at the macro context (Tursilowati, 2005; Tursilowati, et al., 2012; Manik and Syaukat, 2015; Rushayati et al., 2016), therefore, research related to strategic mitigation UHI on a micro/urban design scale is still required.

Bandung is a city with a fairly high population growth, reaching 2,503,710 inhabitants in 2018 with an average growth rate of $1.01 \%$ per year. High population growth rate contributed to the rapid development of the built environment leading to increase in temperature. Data measurement at Bandung Weather Station showed that the maximum temperature trends reached $35^{\circ} \mathrm{C}$ in the $2001-2010$ decade. Remote sensing study from LANDSAT data stated that the UHI areas (areas with surface temperatures above $30^{\circ} \mathrm{C}$ ) at the Bandung basin had been expanded in 1994 to 2001 due to the rapid changes in land cover (Tursilowati, 2005). Areas with high temperatures are located in the downtown area and expand to the suburbs due to widespread changes in land use. Bandung is also a city with a lot of tropical heat gain when compared to the subtropical city because of the large concentration of solar radiation at the equator so UHI can give more negative effects to thermal comfort of city residents. 
UHI in Bandung is influenced by coefficient of mass and building form and building materials characteristic (Wonorahardjo, 2010). In general, buildings in Bandung also doesn't pay attention to the harmony of mass and form of the building with the surrounding. Beside, in certain areas, the building utilization likely to be multifunctional building and there are pockets of densely settlement that surrounded by commercial areas. Those problems emphasize that the implementation of UHI mitigation strategy in Bandung becomes more difficult when compared to the city with the uniform building mass and have good spatial planning.

Vegetation is lowering the temperature through evapotranspiration and shading (US EPA, 2012). The number of parks contributes to lower the temperature around the park and to mitigate urban heat (SpronkenSmith et al., 1998; Upmanis et al., 1998; Oke et al., 1989; Ca et al., 1998; Wattkins et al., 2002; Chen et al,. 2006; Hamada and Ohta, 2009; Skoulika et al., 2014; Bowler et al., 2010). Vegetation can reduce the air temperature by $0.2^{\circ} \mathrm{C}-1,2^{\circ} \mathrm{C}$ around the land surface through evapotranspiration (Kleerekoper, 2009). However, trees require sufficient area so they can grow properly. Hot temperature mitigation in the dense areas can be implemented by combining vegetation on building facades through green roof and green wall. Building materials pavement have different albedo (the ability of a material to reflect heat). If a material have high albedo value, that material will stay cold when exposed to direct sunlight. In general, buildings and pavement in the city area are composed by heavy materials that easily absorb heat and have a low albedo value. Modification of pavement construction materials in order to provide thermal comfort can use cool roof and cool pavement. Narrow street and tall building also formed a canyon which trap solar radiation. Based on literature review preceding UHI mitigation research and theory of urban design elements, the study has obtained the requirements of mitigation strategy application as mentioned on Table 1 .

\section{METHODOLOGY}

This study was using deductive and inductive approach. Deductive approach was used to conclude UHI mitigation prerequisites from literature review about UHI preliminary research, UHI mitigation precedents, and urban design elements using content analysis method. Inductive approach was applied by formulated the structure of the existing problems in the downtown area, formulate laws and regulations relating to the application form UHI mitigation, and to compare that existing problem structure with application prerequisites of UHI mitigation. Stuctural problems in the downtown area were formulated using exploratory analysis method that aimed to clarify the application of mitigating UHI issues in the downtown area. Comparative analysis method was used to compare the conditions in the study area with UHI mitigation prerequisites.

The study area is located in downtown area of Bandung specifically on Kecamatan (sub-district) Sumur Bandung. The area is affected by tropical climate condition with average temperature around $23.6^{\circ} \mathrm{C}$. Based on temperature measurement by local meteorological station, average temperature increases around $0.012^{\circ} \mathrm{C}$ per year. There was an increase in maximum temperature around $0.95^{\circ} \mathrm{C}$ on 1980 to 2010. During the day, the temperature rises extremely, reached $35^{\circ} \mathrm{C}$ in the decade 2001 to 2010 . Besides the lowest minimum temperature has been increased by $0.7^{\circ} \mathrm{C}$, which indicated temperature is getting hotter. High surface temperatures contribute to high air temperatures although the surface temperature is more variable than the air temperature.

High surface temperatures contribute to high air temperatures although the surface temperature varies than the air temperature. The location of highest surface temperature in 2012 can be seen in Figure 1. Based on surface temperature distribution map, high surface temperatures $\left(26-32^{\circ} \mathrm{C}\right)$ tends to be on the western part of of Bandung. There are some areas with low surface temperatures on the eastern part of Bandung because land cover is dominated by rice fields and lack of built area. From these maps, it can be concluded that the downtown area and western part of Bandung has a higher temperature than other parts of Bandung.

Surface temperature on the study area (Figure 2) indicated that Urban Heat Island occurs. The surface temperature ranged from $21,3-32^{\circ} \mathrm{C}$. That temperature variation occured because there are differencies on urban morphology. Western part of study area is hotter than the eastern part because the buildings on that area are dense and lack of green space. The western area is consisted of commercial area (row of retail buildings) and densely residential area. Hot temperature on the western part also triggered with corrugated building materials that have low albedo values. The area around the river bank has low temperature $\left(22^{\circ} \mathrm{C}\right)$ because there are lot of trees that give shade effect to the pavement. 
Table 1. UHI Mitigation Prerequisites

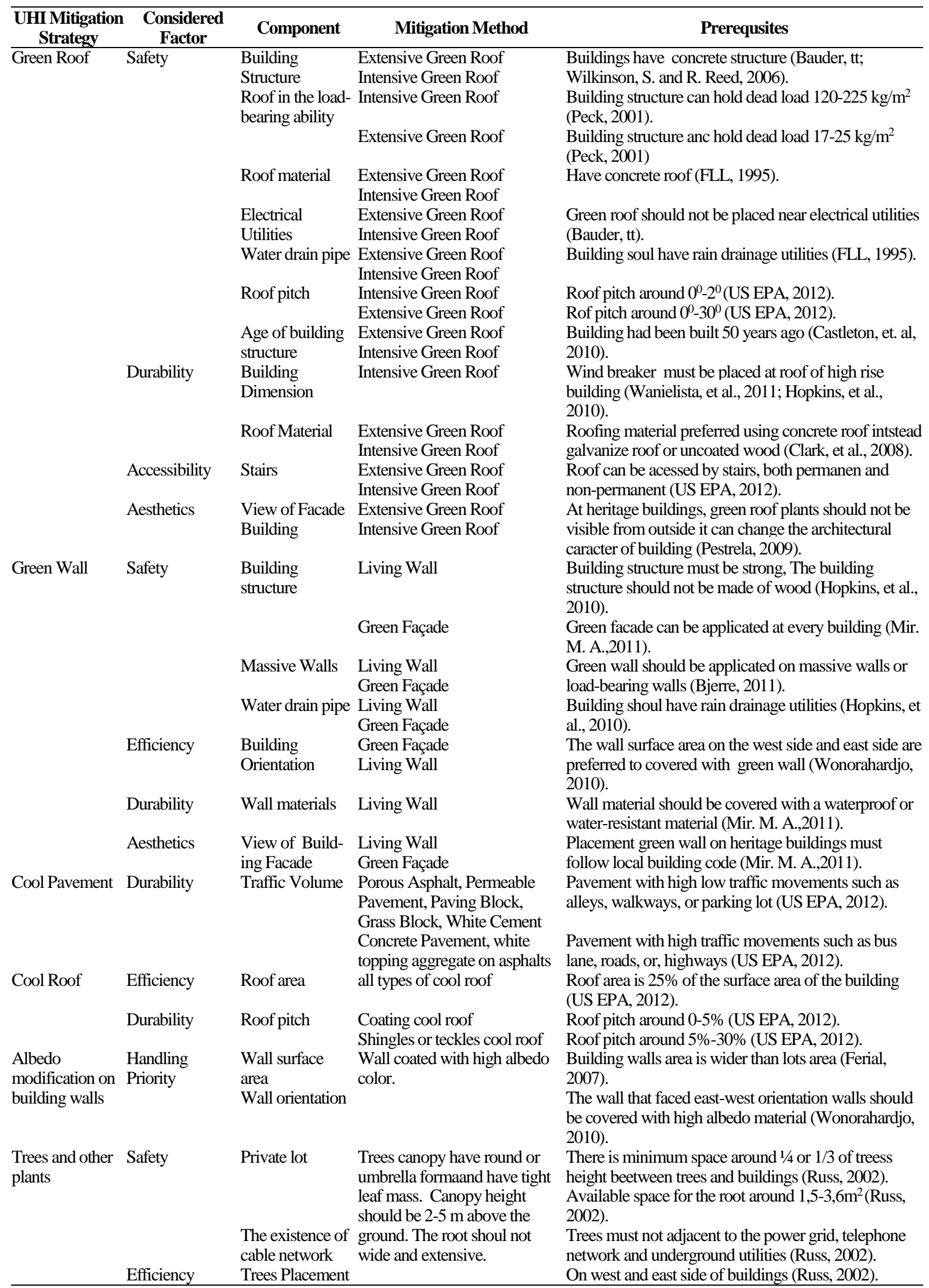




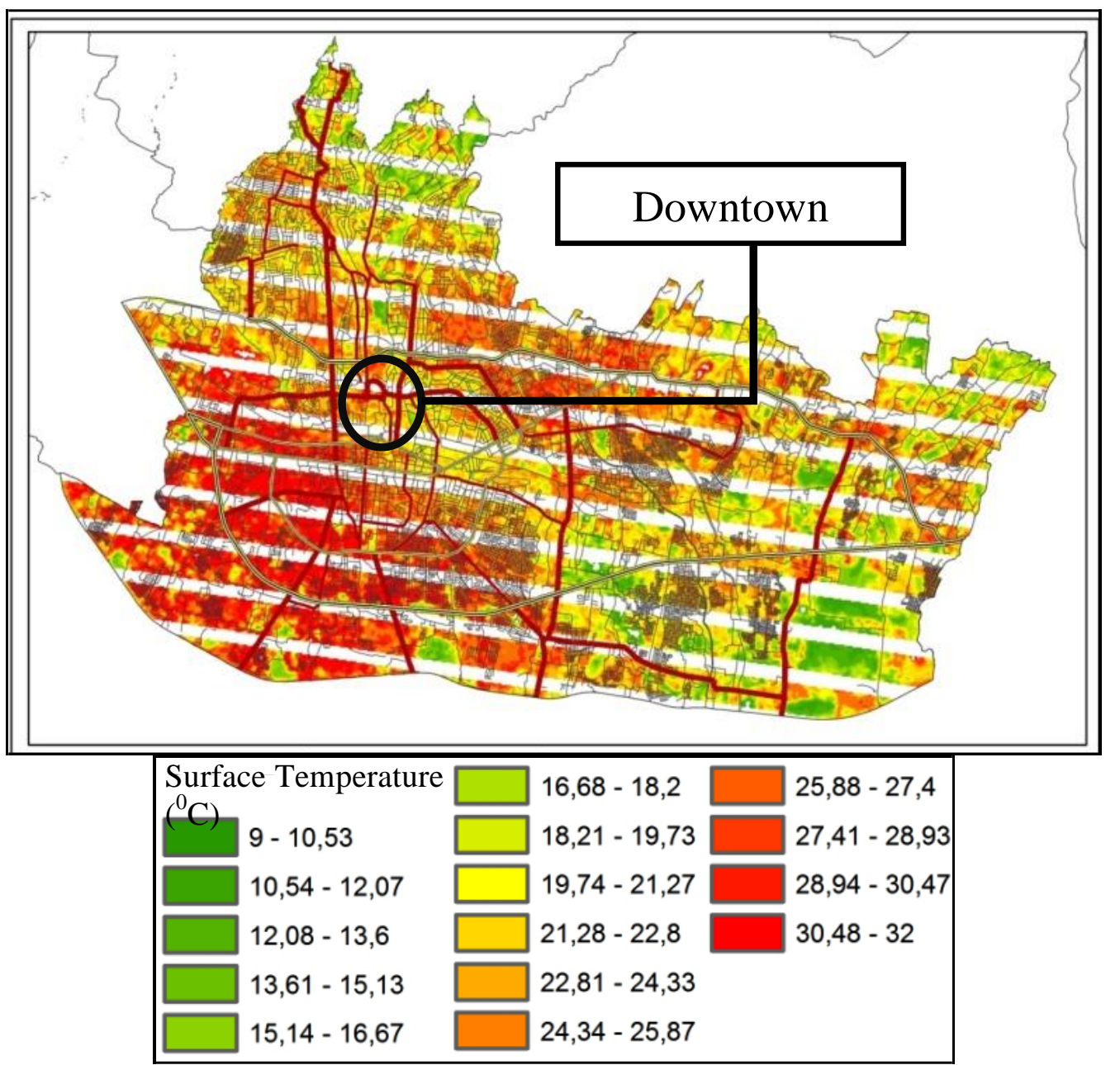

Fig. 1. Bandung Surface Temperature Map (August, 2012)

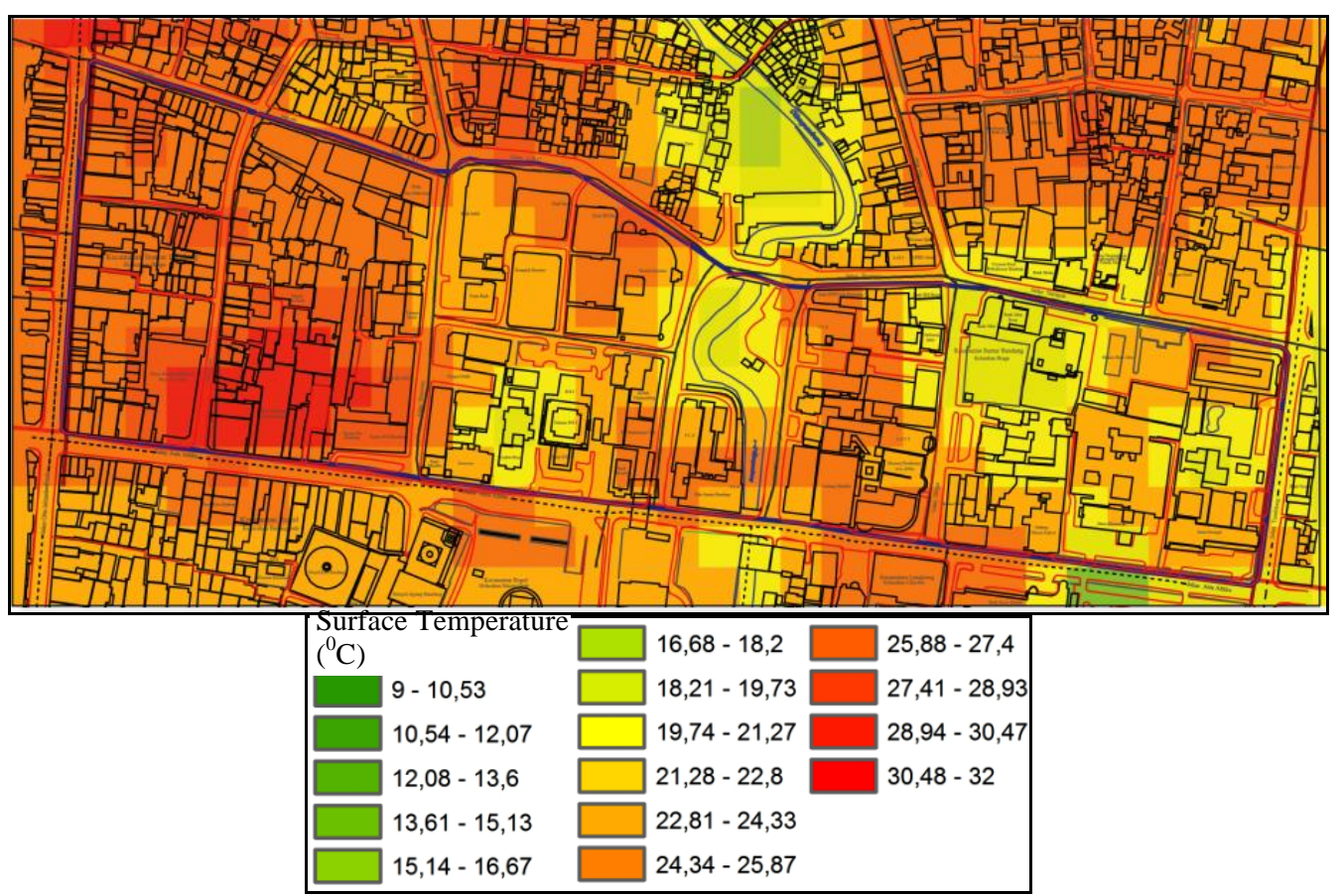

Fig. 2. Surface Temperature Distribution on Study Area (August, 2012) 


\section{RESULTS AND DISCUSSION}

To facilitate observation of the study area, the study area is divided into five blocks of observations (Fig. 3). These divisions based of the numbers of blocks that exist in the study area and did not consider the similarity of building typologies or other physical characteristics. The components that are observed include physical components that should be intervened by implementation of UHI mitigation. The results of observations of the study area can be seen in Table 2. Both internal and external physical components in study area are compared with mitigation prequirements to determinate appropriate UHI mitigation strategy that can be adaptable with physical components of study area. Typologies of existing buildings in the study area include new and old shophouses, high rise buildings, one or two floors residential buildings, three and four floors residential building, and heritage building. The results from that comparison analyst is a form of UHI mitigation that adaptable with the typology of the building as well as the physical characteristics of the downtown area. The UHI mitigation principles and application on new shophouses, mentioned on Table 3 .

After the study of UHI mitigation strategy on building typologies and external physical characteristics of each blocks the next stage is determining the location of the application UHI mitigation strategy that was discussed as well as the number of parcels and buildings that can be applied with mitigation strategy.

Table 2. Description of Internal and External Physical Components

\begin{tabular}{|c|c|c|c|c|c|}
\hline Component & Block A & Block B & Block C & Block D & Block E \\
\hline \multicolumn{6}{|c|}{ INTERNAL PHYSICAL COMPONENTS } \\
\hline $\begin{array}{l}\text { Number of } \\
\text { Buildings }\end{array}$ & 14 & 37 & 104 & 86 & 122 \\
\hline $\begin{array}{l}\text { Building } \\
\text { Height }\end{array}$ & $1-11$ floors & $1-4$ floors & $1-8$ floors & $\begin{array}{l}\text { 1-4 floors, } \\
\text { formed urban canyon }\end{array}$ & $\begin{array}{l}1-4 \text { floors, formed } \\
\text { urban canyon }\end{array}$ \\
\hline $\begin{array}{l}\text { Building } \\
\text { Coverage } \\
\text { Ratio }\end{array}$ & $50-60 \%$ & $70-100 \%$ & $50-70 \%$ & $90-100 \%$ & $90-100 \%$ \\
\hline Roof Materials & $\begin{array}{l}44 \% \text { of buildings } \\
\text { use concrete roof }\end{array}$ & $\begin{array}{l}28.9 \% \text { of buildings use } \\
\text { terracotta roof } \\
24.4 \% \text { of buildings use } \\
\text { concrete roofs }\end{array}$ & $\begin{array}{l}70.17 \% \text { of building } \\
\text { use mix-materials } \\
\text { roofs }\end{array}$ & $\begin{array}{l}57.5 \% \text { of buildings use } \\
\text { terracotta roofs } \\
27 \% \text { of buildings use } \\
\text { concrete roofs }\end{array}$ & $\begin{array}{l}52.9 \% \text { of buildings } \\
\text { use terracotta roofs } \\
43.26 \% \text { of buildings } \\
\text { use concrete roofs }\end{array}$ \\
\hline $\begin{array}{l}\text { Building } \\
\text { Structure }\end{array}$ & $\begin{array}{l}\text { Almost all buildings } \\
\text { have concrete } \\
\text { structures }\end{array}$ & $\begin{array}{l}\text { Almost all buildings } \\
\text { have concrete structures }\end{array}$ & $\begin{array}{l}\text { Almost all buildings } \\
\text { have concrete } \\
\text { structures }\end{array}$ & $\begin{array}{l}\text { Almost all buildings } \\
\text { have concrete structures }\end{array}$ & $\begin{array}{l}\text { Almost all buildings } \\
\text { have concrete } \\
\text { structures }\end{array}$ \\
\hline Drain Pipe & $\begin{array}{l}\text { All buildings have } \\
\text { drain pipe }\end{array}$ & $\begin{array}{l}\text { All buildings have drain } \\
\text { pipe }\end{array}$ & $\begin{array}{l}\text { All buildings have } \\
\text { drain pipe }\end{array}$ & $\begin{array}{l}\text { All buildings have drain } \\
\text { pipe }\end{array}$ & $\begin{array}{l}\text { All buildings have } \\
\text { drain pipe }\end{array}$ \\
\hline $\begin{array}{l}\text { Yard or } \\
\text { Parking Lot }\end{array}$ & $\begin{array}{l}\text { Almost all buildings } \\
\text { lot have yard and } \\
\text { parking area }\end{array}$ & $\begin{array}{l}\text { Almost all buildings lot } \\
\text { have yard and parking } \\
\text { area }\end{array}$ & $\begin{array}{l}\text { Almost all buildings } \\
\text { lot have yard and } \\
\text { parking area }\end{array}$ & $\begin{array}{l}\text { Almost all buildings lot } \\
\text { don't have yard and } \\
\text { parking area }\end{array}$ & $\begin{array}{l}\text { Almost all buildings } \\
\text { lot don't have yard } \\
\text { and parking area }\end{array}$ \\
\hline \multicolumn{6}{|c|}{ EXTERNAL PHYSICAL COMPONENTS } \\
\hline $\begin{array}{l}\text { Width of } \\
\text { Pedestrian } \\
\text { Walk }\end{array}$ & $1.5-3 \mathrm{~m}$ & $1.5-5 \mathrm{~m}$ & $1.5-3 \mathrm{~m}$ & 86 & 122 \\
\hline Green Belt & $\begin{array}{l}\text { Potted medium } \\
\text { trees and shrubs on } \\
\text { pedestrian walk }\end{array}$ & $\begin{array}{l}\text { Potted medium trees } \\
\text { and shrubs on } \\
\text { pedestrian walk }\end{array}$ & $\begin{array}{l}\text { Potted medium trees } \\
\text { and shrubs on } \\
\text { pedestrian walk }\end{array}$ & $\begin{array}{l}\text { Potted medium trees } \\
\text { and shrubs on } \\
\text { pedestrian walk }\end{array}$ & $\begin{array}{l}\text { Medium trees on } \\
\text { shoulder of the road. }\end{array}$ \\
\hline Utilies Cable & $\begin{array}{l}\text { Power network and } \\
\text { telephone cable } \\
\text { above the ground. }\end{array}$ & $\begin{array}{l}\text { Power network and } \\
\text { telephone cable above } \\
\text { the ground. }\end{array}$ & $\begin{array}{l}\text { Power network and } \\
\text { telephone cable above } \\
\text { the ground. }\end{array}$ & $\begin{array}{l}\text { Power network and } \\
\text { telephone cable above } \\
\text { the ground. }\end{array}$ & $\begin{array}{l}\text { Power network and } \\
\text { telephone cable above } \\
\text { the ground. }\end{array}$ \\
\hline Parking Area & On street parking & $\begin{array}{l}\text { On street parking } \\
\text { parking and parking } \\
\text { area beside the river } \\
\text { bank }\end{array}$ & On street parking & On street parking & On street parking \\
\hline River bank & - & $\begin{array}{l}\text { The river bank width is } \\
\text { around } 10-22 \mathrm{~m} \text {. There } \\
\text { are some big trees on } \\
\text { green belt beside the } \\
\text { river bank. }\end{array}$ & - & - & - \\
\hline
\end{tabular}


Table 3. Application of Mitigation Strategy in Each Building Typology

\begin{tabular}{|c|c|}
\hline $\begin{array}{c}\text { Physical } \\
\text { Components }\end{array}$ & Problem Characteristics \\
\hline $\begin{array}{l}\text { Building } \\
\text { Dimension }\end{array}$ & 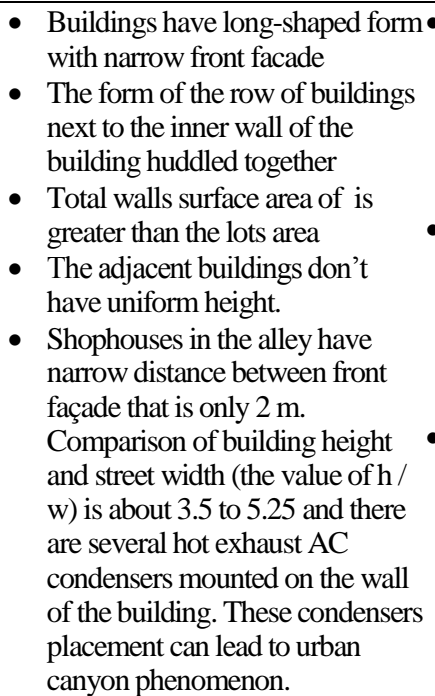 \\
\hline
\end{tabular}

Handling Principles

Building coincide with other buildings so the parts that exposed to - Green wall can only cover $20 \%$ of the direct sunlight are the roof and the front facade of the building. These parts should be covered by a material that can reflect the heat.

- If there is a height differences at the adjacent building, the taller building's wall is also painted with reflective color to avoid absorption of the reflected heat from the roof of a lower building.

Avoid heat trapping in the building which located in the alley by coating the entire wall of the building with brightly colored paint or cover the walls with green wall.

Green wall building facade face.

- Green wall can only install on second of first floor is opened as display. use bricks as wall materials

- Suggested to use green facade system with soil is placed on existing building In building with flat roof, of soil media placed on roof. Plants used on a green facade is vines so the plants can cover most of the facade
Application of Mitigation Strategies floor and above because the front facade

- Green wall installed on buildings which structures such as floor balcony or at the space between the window and the wall.

- Green wall should be placed on east and west facing wall. The facade side of the building that exposed to the sun is not installed with green roof by considering the possibility of the building next door will be elevated.

- At building that is covered with aluminum billboards on the front facade, a green facade media placed on the space between the wall and the aluminum plate. Green facade uses climbing plants without supporting structure. The plants shouldn't have large-diameter leaf so the billboard message still can be seen.

- Green wall structure can be placed on the front facade shop, precisely the structure is installed outside the plot or on the pedestrian walk. Construction is mounted on the column. The structure can be used as a propagation direction of the vines to the second floor of the building facade. Soil medium can be positioned just below the cantilever construction as in the shop porch, sidewalk, or on top of drainage.

- Growing media can be installed over openings in the cantilever construction of first floor or placed on the edge of the roof (flat roof). Planting media should use the media as light as pumice with hydroponic system.

- In building with a glass facade, green wall has limited installation. Green wall can only be installed at the structure parts that hold glass structure. The growing media placed on the sidewalk or on the flat roof.

- It's difficult to place green wall media around the storefront at alley because the space is narrow and filled with street vendors. Growing media of green wall can be placed on the second-floor balcony.

Other mitigation strategy.

- The walls of the building that can't be installed with green wall should be repainted with bright colors that are reflective, prioritized on the eastern or western wall 


\begin{tabular}{lll}
\hline $\begin{array}{c}\text { Physical } \\
\text { Components }\end{array}$ & Problem Characteristics & Handling Principles \\
\hline & & \\
Building & The building structures use & The structure of the walls and columns \\
Structure & reinforced concrete. & that can withstand green wall required \\
& & additional construction.
\end{tabular}

Application of Mitigation Strategies

- The rear of the building that is not attached to the other buildings was painted with white color to avoid heat absorption.

- AC condensers can be mounted on the front of the building that leads to a major street or on the 3rd floor to the top so the heat emissions can be directly released into the sky.

- The glass facade must be coated with reflective glass film.

Almost all of shophouse buildings can be retrofitted with considering the availability of space for growing media as well as the existence of massive walls.

- The roof part of the building is most Cool Roof exposed to the hot sun so the building $\bullet$ Installing a cool roof is prohibited for should use a roofing material that has a high albedo, so the direct heat is reflected back.

Building

- Most buildings use white flat concrete roof. Some buildings have additional roof with clay tile and aluminum plate.

- The roofs functioned as a place to store the utility of air conditioners, water storage, complementary buildings and large-sized antenna

- By law the building load of Indonesia 1983; all flat-roofed building is able to sustain additional live load with a total of $100 \mathrm{~kg} / \mathrm{m} 2$. If the building is capable of supporting the load generators, large antennas, or building complement the building must be withstand load that exceed $100 \mathrm{~kg} / \mathrm{m}^{2}$ live load, reaching a maximum of 250 $\mathrm{kg} / \mathrm{m}^{2}$.

- There are potted plants that placed on the roof in some buildings with flat roofs.

- A number of buildings with flat roofs have dull conditions roof so the color is getting darker.

- The buildings with steep-slopped roof use clay tile, ceramic tile, and aluminum plate.

- Building with clay tile roofs have dull roof shape and experienced darkening of color while a number of buildings with metal roofs such as aluminum are rusty.
- Installing a cool roof on a steepsloped roof or shingle roof with high albedo value.

- Installing a cool roof on a flat roof use a reflective coating. steep-sloped roofs because the roofs are vulnerable to support the added weight of the green roof. There is no permanent access to the steep-slope roof.

- Cool roof can be installed to most flat roofs roof area functioned for people activities such as drying clothes. Installing a cool roof should also be applied to the flat roof with electricity were installation tool that occupies most of the roof area. This is to avoid the occurrence of a fire when the fire spillovers.

- Buildings with steep-sloped roofs using terracotta clay tile or ceramic tile. The material suited to the tropical climate so that the mitigation strategy application is just repainted. Cool roof installation on steep-sloped roofs can also use metal roof painted with bright color

- Flat roof buildings using cool roof coatings in the form of liquid spray that contain cement particle on the roof

\section{Green Roof}

- Green roof is applied if most of the building roof is a concrete flat roof. There should be a buffer zone (buffer) with a width of $1.5 \mathrm{~m}$ between the location of the green roof and electric utility tools to avoid spillovers fire.

- Green roof that can be applied in the area is extensive green roof using lightweight media such as rock wool or pumice stones with a total weight of green roof installation should not exceed $10 \mathrm{~kg} / \mathrm{m} 2$. This is to avoid excessive load because the existing roofs are not designed to accommodate a green roof. Plants used in the green roof are grasses or shrubs.

- Green roof plants using media such low specific gravity pumice $(0.6-0.7 \mathrm{~kg} / \mathrm{l})$ or synthetics material such as rock wool with a density from 0.04 to $0.05 \mathrm{~kg} / \mathrm{l}$. Plants need fertilizer and watering periodically through the custom installation of water drain 


\begin{tabular}{|c|c|c|c|}
\hline $\begin{array}{l}\text { Physical } \\
\text { Components }\end{array}$ & Problem Characteristics & Handling Principles & Application of Mitigation Strategies \\
\hline uilding yard & $\begin{array}{l}\text { - Most of the buildings don't have } \\
\text { a yard. } \\
\text { - Cluster shaped buildings have } \\
\text { green belt along the fence or } \\
\text { wall. } \\
\text { - In some building lot that does not } \\
\text { have a yard; building owners put } \\
\text { potted plants on the front porch } \\
\text { or on the flat roof. } \\
\text { - Building coverage area around } \\
60-100 \% \text {. }\end{array}$ & $\begin{array}{l}\text { On the limited plot area, the green } \\
\text { yard can be made in the form of } \\
\text { vertical garden (green roof or green } \\
\text { wall). } \\
\text { - Green belt in shophouse cluster used } \\
\text { efficiently for planting trees. }\end{array}$ & $\begin{array}{l}\text { - Placing potted plants around the patio or } \\
\text { pedestrian walk. The placement of potted } \\
\text { plants should not interfere with the } \\
\text { circulation of visitors shop and } \\
\text { pedestrians. } \\
\text { - Potted plants can be placed on the balcony } \\
\text { or by using hanging pots on the front } \\
\text { facade if space is available. }\end{array}$ \\
\hline $\begin{array}{l}\text { Parking and } \\
\text { Driveway } \\
\text { Pavement }\end{array}$ & $\begin{array}{l}\text { 1- Shophouses on Banceuy Cluster } \\
\text { dan Braga Cluster have a parking } \\
\text { area wider than green area. } \\
\text { - Most of the parking lots using } \\
\text { black asphalt as pavement. } \\
\text { - Parking lots not covered by tree } \\
\text { shading. } \\
\text { - The road network on shophouse } \\
\text { Cluster using black asphalt. }\end{array}$ & $\begin{array}{l}\text { Parking and driveway using porous } \\
\text { pavement to prevent rainfall runoff so } \\
\text { the water can flow into the ground } \\
\text { under the pavement, thereby reducing } \\
\text { the heat-absorbing pavement. } \\
\text { bright color so heat can be reflected. } \\
\text { barking lots pavement must have }\end{array}$ & $\begin{array}{l}\text { Cool Pavement } \\
\text { - Parking pavement on Braga Cluster can } \\
\text { use porous paving or grass block. } \\
\text { - Porous paving block should be brightly } \\
\text { colored and have routine maintenance to } \\
\text { avoid darkening of color. } \\
\text { - Plants wide canopy tree around the } \\
\text { parking lots so the pavement cannot } \\
\text { absorb the sun heat. } \\
\text { - Driveway and path in shophouse cluster } \\
\text { should use a permeable paving block with } \\
\text { light color. }\end{array}$ \\
\hline Fences & $\begin{array}{l}\text { - On Braga Cluster, plot is fenced } \\
\text { with } 5 \mathrm{~m} \text { height brick wall. } \\
\text { - On Banceuy Cluster, plot area is } \\
\text { fenced with metal fence. }\end{array}$ & $\begin{array}{l}\text { - Life fence system } \\
\text { can reduce air ten } \\
\text { - Wall fences can b } \\
\text { structure of living }\end{array}$ & $\begin{array}{l}\text { - Living wall system with a planter box or } \\
\text { vertical growing media can be installed on } \\
\text { wall fences of Braga Cluster. } \\
\text { - Static metal fenced in Banceuy Cluster } \\
\text { can be used as a green facade structure. }\end{array}$ \\
\hline
\end{tabular}

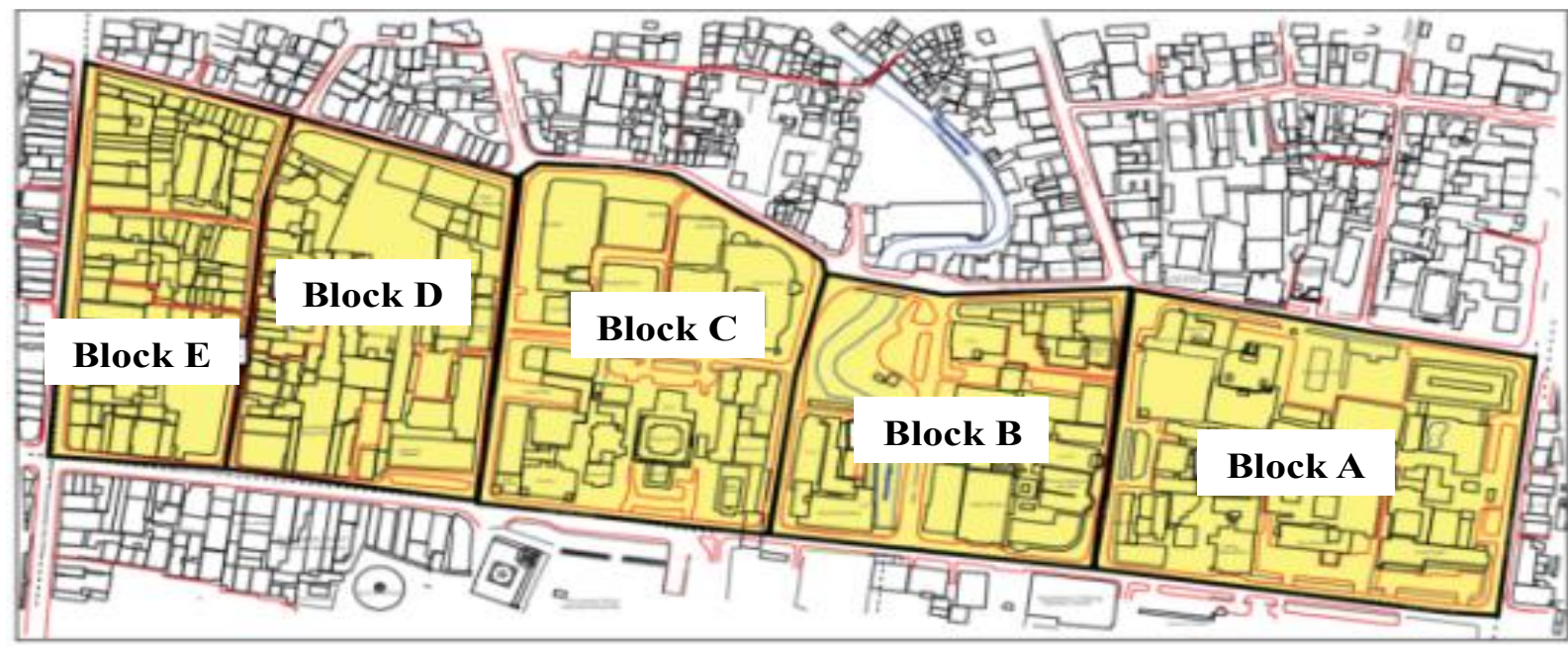

Fig. 3. Observation Blocks

Green Roof. Flat roof buildings in the study area have concrete roof, concrete columns, rain drainages, and permanent access. These criteria are usually owned by the new shophouses and high rise building typologies. In the study area, many buildings with flat roofs have been modified by the owner of the building so that the building has an additional building in the form of permanent or semi-permanent building on the roof with a roof covering of zinc, aluminum, or asbestos materials. That cause the buildings are vulnerable to additional dead load on the roof. In addition, the roof of these buildings only have limited space that is located at the edge of the roof therefore placing a green roof system might be vulnerable. Most of flat roof are used for drying clothes or other residents activities so it's difficult to install a green roof. Type of extensive green roof light with additional dead load of $10-25 \mathrm{~kg} / \mathrm{m}^{2}$ applied to a new shop building typology with criteria that refers to the National Building Load Regulation 1983. High rise buildings that were designed to accommodate a permanent building on the roof can accommodate the intensive green roof system using shrubs or small plants with soil as plants medium. Therefore, resulted the numerous buildings that can accomodate green roof which can be seen on Table 4 and Figure 4 . 
Table 4. The number of buildings that can accomodate green roof system

\begin{tabular}{llc}
\hline Block & Green Roof Types & Number of Buildings \\
\hline \multirow{2}{*}{ Block A } & Extensive Green Roof & 2 \\
& Intensive Green Roof & 4 \\
\multirow{2}{*}{ Block B } & Extensive Green Roof & - \\
& Intensive Green Roof & 1 \\
\multirow{2}{*}{ Block C } & Extensive Green Roof & 11 \\
& Intensive Green Roof & 2 \\
\multirow{2}{*}{ Block D } & Extensive Green Roof & 18 \\
& Intensive Green Roof & - \\
\multirow{2}{*}{ Block E } & Extensive Green Roof & 15 \\
& Green Roof & 1 \\
\hline Total & & $\mathbf{5 4}$ \\
\hline
\end{tabular}

Table 5. The number of buildings that can accomodate green roof system

\begin{tabular}{ll}
\hline Observation Blocks & Number of Buildings \\
\hline Block A & 8 \\
Block B & 37 \\
Block C & 104 \\
Block D & 80 \\
Block E & 97 \\
Total & $\mathbf{3 2 6}$ \\
\hline
\end{tabular}

Green Wall.Green wall is a vertical placement of plants, either attached to the building wall or on a stand-alone structure. The purpose of green wall installation at UHI mitigation is to reduce the area of building walls that exposed to the sunlight. In order to accommodate green wall system must meet the requirements to have a solid wall structure that has enough space to put a green wall system. Green wall is difficult to be placed on the front facade of the building with a dominant form of unstructured wall such as aluminum plate for advertisement or glass material dominance. Green wall also can not be mounted on the walls of heritage buildings as it can be categorized as an additional ornament unrelated to the initial architecture of the heritage buildings. Buildings that were not built according to standards such as residential house can use simple green wall system with hanging potted plants. Buildings that have priority to install green wall in west and east faced buildings. Number of buildings and building locations that can accommodate the installation of a green roof can be seen in the Table 5. and Figure 5.

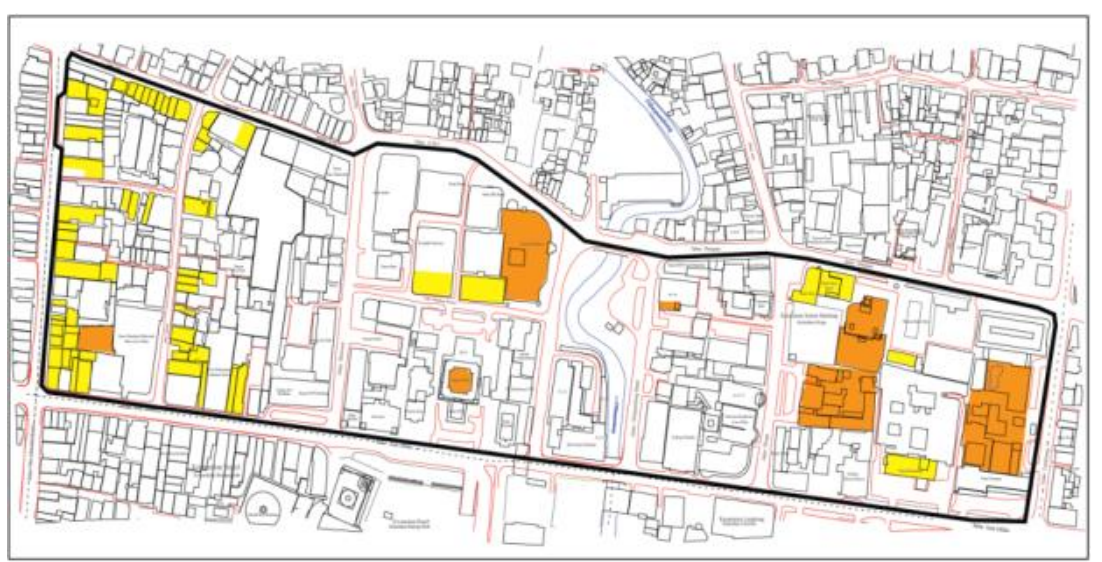

Study Area

$\square$ Extensive Green Roof

$\square$ Intensive Green Roof

Fig. 4. Location of Buildings that can accomodate Green Roof System

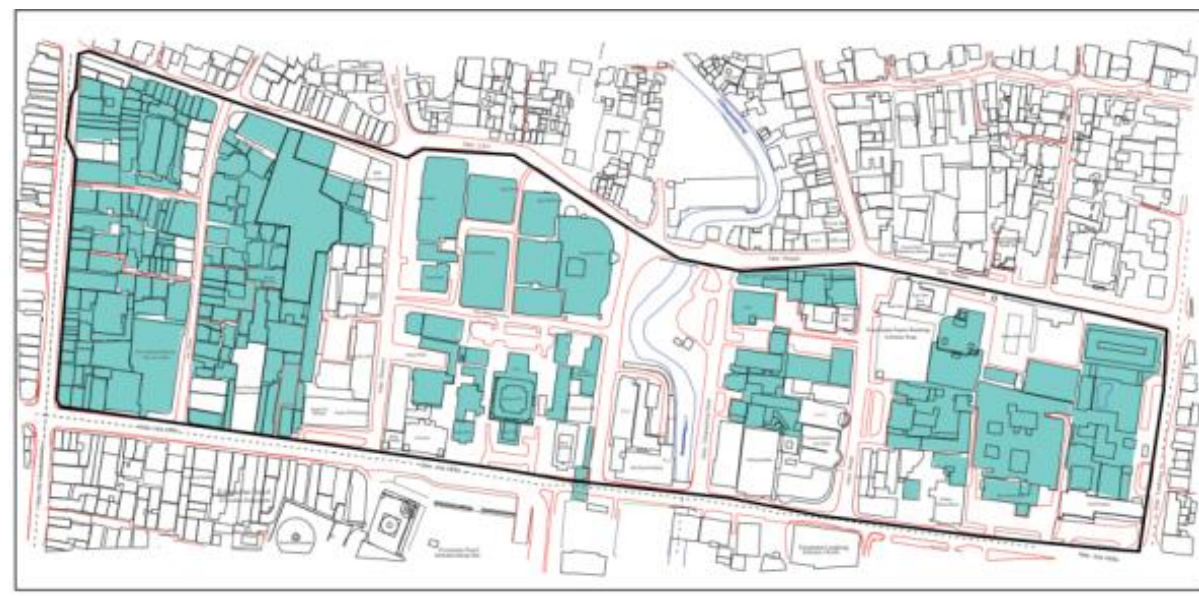

Study Area

Green Wall

Fig. 5. Location of Buildings that can Accomodate Green Wall System 
Albedo Material Modification. Albedo modification can be applied on all buildings and pavement. Albedo modification with cool roof and wall coating material method can applied on any building, especially to the dull building. Albedo modification on the pavement based on the movement of the load passing on the pavement. Cool pavement in the form of porous paving or grass block applied to the parking lot and drive way in the plot. The total area of pavement parking that can be mitigated is about 8,256 $\mathrm{m}^{2}$. Highway pavement that can be mitigated by using bright colored aggregate with a total area of pavement reach $12,700 \mathrm{~m}^{2}$.

Trees Mitigation. The trees planting applied on plots of land that has enough space (Buildind Coverage Ratio below $70 \%$ ) but does not have a shade tree in the yard. The trees can be planted on a plot boundary with the pavement so the trees can provide shading to the sidewalk in front of him. The planting of trees in the plot can be applied to a BJB Tower, West Java Tourism Office, Commercial Complex Braga, Bank Training Center (Nedhandel), BRI Tower, PT Waskita, Cikapundung Pharmacy, Cikapundung Parking Area, Hotel Ibis, Banceuy Permai Cluster, Natraco, Panin Bank, Post Office, Hotel Golden Flower a parking lot at the shop. Green belt which located beside the sidewalk is maintained. Plants the trees on the pavement directly into the ground so that the roots have space to grow. Height and width of the tree canopy in green belt adjacent to the building is maintained to prevent damaging the building. The narrow sidewalk can use the pergola as a green line. A pergola can be placed on the sidewalk on the side of the river along Jl. Cikapundung Timur.

\section{CONCLUSION}

On this study, UHI mitigation strategy applied by manipulating the amount of heat energy that absorbed by the building and land cover materials. UHI mitigation strategies described in this paper aim to:

a. Decrease the absorption of thermal energy by raising the albedo in areas exposed to the sun

b. Lowering the heat radiation absorption by covering the physical building, sidewalks and parking lots with green roof and green wall system.

The mitigation strategy cannot be applied to every buildings dan physical environments in the downtown area because not all buildings have a same physical condition. In addition, each owner of buildings has modified the building form or changes some material parts so the buildings have changed from its original form. In contrast to European countries, Bandung does not have specific regulations regarding the criteria on building facade modification. This causes the application UHI mitigation strategy in a couple adjacent buildings may be different. A number of local regulations regarding the physical components and the configuration of the building mass has led of UHI intensity reduction. However, due to the lack of regulation enforcement, assumed the UHI phenomenon can not be handled properly. The reason that the lack of rules application is because the regulation is not equipped with complementary rules that contained a detailed form about application mitigation such as design guidelines.

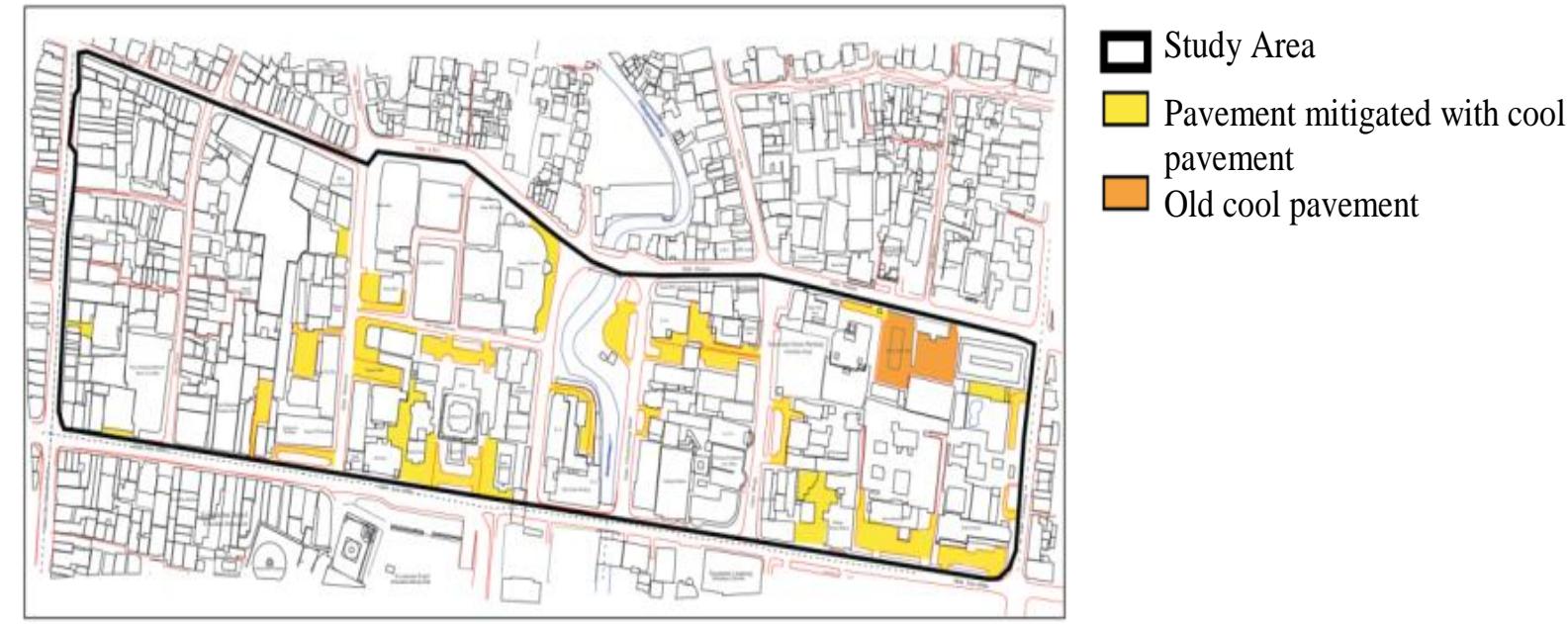

Fig. 6. Location of Pavement that can be Mitigated by Cool Pavement 
Comparison between UHI prerequisites and physical condition of the study area resulted UHI mitigation strategies that can be applied as follows,

a. There are 43 buildings or as much as $12.4 \%$ from total buildings that can accommodate extensive green roof system.

b. There are 46 buildings or as much as $13 \%$ from total buildings that can accommodate the application of extensive green roof.

c. There are 8 buildings or as much as $2.26 \%$ from total building that can accommodate the implementation of an intensive green roof.

d. There are 326 buildings or as much as $92.1 \%$ from total building that can accommodate green wall. Almost all buildings can accommodate green facade system.

e. All buildings can accommodate the application of cool roof and wall material and match the albedo modification.

f. The total area of parking pavement that can be mitigated by using porous paving or grass block is $8,256 \mathrm{~m}^{2}$ or as much as $3.84 \%$ of the total area .

g. The total area of parking pavement that can be mitigated by using porous paving or grass block is $12,700 \mathrm{~m}^{2}$ or about $5.9 \%$ of the total area of the study .

h. Planting more threes for shade trees on 18 plots.

i. Maximizing the green belt and the yard is difficult on block $\mathrm{E}$ because space is limited.

\section{REFERENCES}

Akbari, H., \& Kolokotsa, D. (2016). Three Decades of Urban Heat Islands and Mitigation Technologies Research. Energy and Building. 133, 834842.

Bauder. (tt). Green Roof Guide: Design Consideration. United Kingdom. Bauder Limited.

Bjerre, L.A. (2011). Green Walls. 7 Semester Dissertation. Bachelor of Architect Technology and Construction Management. VIA University College, Horsens, Denmark. Published on November 28th.

Bowler, D.E., Buyung-Ali, L., Knight, T.M., \& Pullin, A.S. (2010). Urban Greening to Cooltowns and Cities: a Systematic Review of the Empirical Evidence. Landscape and Urban Planning. 97, 147-155.

Ca, T.V., Asaeda, T., \& Abu, E.M. (1988). Reductions in Air Conditioning Energy Caused by a Nearby Park. Energy and Buildings. 29, 83-92.

Castleton, H. F., Stovin, V., Beck, S.B.M., \& Davidson, J.B. (2010). Green Roofs: Building Energy Saving s and The Potential for Retrovit. Energy and Buildings, 42(10), 1582-1591.
Chen, Y., \& Wong, N.H. (2006). Thermal Benefits of City Parks. Energy and Buildings. 38, 105-120.

Clark, S., Long, B.V., Siu, C.Y.S., \& Spicer, J. (2008). Early-life Runoff Quality: Green Versus Traditional Roofs. Low Impact Development 2008. Seattle, WA. American Society of Civil Engineers.

Ferial, R. (2007). Bangunan Tinggi dan Lingkungan Kota. Teknik A, 28(1), 92-97.

Forschungsgesellschaft Landschaftsentwicklung Landschaftsbau/FLL. (1995). Guidlines for the Planning, Execution, and Upkeep of Green-roof sites. Bohn: Germany.

Hamada, S., \& Ohta, T. (2010). Seasonal Variations in the Cooling Effect of Urban Green Areas on Surrounding Urban Areas. Urban Forestry \& Urban Greening, 9(1), 15-24.

Hopkins, G., Goodwin, C., Milutinovic, M., \& Andrew, M. (2010). Living Wall System for Multi-storey Building in the Adelaide Climate. The Government of South Australia: Adelaide.

Kleerekoper, L. (2009). Urban Heat: Design Priciples for Urban Heat Management in the Netherlands. Dissertation of Delft University of Technology, Netherland.

Manik, T.K., \& Syaukat, S. (2015). The Impact of Urban Heat Island. Asian Cities Climate Resilience. Working Paper Series. 13: 2015

Mir. M. A. (2011). Green Facades and Building Structures. Delft University of Technology. Netherland.

Oke, T.R., Crowther, J.M., McNaughton, K.G., Monteith, J.L., \& Gardiner, B. (1989). The Micrometeorology of the Urban Forest [and discussion]. Philosophical Transactions of The Royal Society B Biological Sciences, 324 (1223), 335-349.

Peck, S.W. (2001). Green Roofs: Infrastructure for the 21st Century Exploiting the Last Urban Empire. Interface.

Pestrela, L. (2009). Intrepreting The Secretary of the Interior's Standards of Rehabilitation: Installing Green Roof on Historic Building. Department of the Interior Technical Preservation Service. U.S.

Rushayati, SB., Prasetyo, LB., Puspaningsih, N., \& Rachmawati, E. (2016). Adaptation Strategy Toward Urban Heat Island at Tropical Urban Area. Procedia Environmental Sciences, 33, 221-229.

Russ, T.H. (2002). Site Planning and Design Handbook. McGraw-Hill.

Santamouris, M. 2014. Cooling the Cities-a Review of Reflective and Green Roof Mitigation Technologies to Flight Heat Island and Improve Comfort in Urban Environments. Solar Energy, 103, 682-245. 
Spronken-Smith, R.A., \& Oke, T.R. (1998). The Thermal Regime of Urban Parks in Two Cities with Different Summer Climates. International Journal of Remote Sensing, 19(11), 2085-2104.

Skoulika, F., Santamouris, M., Kolokotsa, D., \& Boemi, N. (2014). On the Thermal Characteristics and the Mitigation Potential of a Medium Size Urban Park in Athens, Greece. Landscape and Urban Planning, 123, 73-86.

Tursilowati, L. (2005). Pulau Panas Perkotaan Akibat Perubahan Tata Guna dan Penutup Lahan di Bandung dan Bogor. Jurnal Sains Dirgantara, 3(1), 43-64.

Tursilowati, L., Tetuko, J., Sumantyo, S., Kuze, H., \& Adiningsih, E. S. (2012). Relationship between Urban Heat Island Phenomenon and Land Use / Land Cover Changes in Jakarta - Indonesia. Journal of Emerging Trends in Engineering and Applied Sciences (JETEAS), 3(4), 645-653.

United States Environmental Protection Agency (US EPA). (2012). Reducing Urban Heat Islands: Compendium of Strategies-Trees and Vegetation.
Upmanis, H., Eliasson, I., \& Lindqvist, S. (1998). The Influence of Green Areas on Nocturnal Temperatures in a High Latitude City (Goteborg, Sweden). International Journal Climatology, 18, 681-700.

Wanielista, N, Minareci, M., Catbas, N., \& Hardin, M. (2011). Green Roof and Wind Loading. FDEP Project number: WM 934. University of Central Florida.

Watkins, R., Palmer, J., Kolokotroni, M., \& Littlefair, P. (2002). The London Heat Island-Surface and Air Temperature Measurements in a Park and Street Gorges. ASHRAE Transactions, 108, 419-427.

Wilkinson, S., \& Reed, R. (2006). Green Roof Retrofit Potential in Central Business District. Property Management, 27(5), 284-301.

Wonorahardjo, S. (2010). Pengaruh Karakteristik Fisik terhadap Fenomena Pulau Panas (Heat Island) Kawasan Kota Bandung. Disertasi Program Studi Arsitektur, Institut Teknologi Bandung. Indonesia. 